\title{
EXTREME WAVE EVENTS IN THE CENTRAL MEDITERRANEAN: GEOMORPHIC EVIDENCE OF TSUNAMI ON THE MALTESE ISLANDS
}

by

\author{
Derek Mottershead, Malcolm Bray*, Philip Soar, Paul J. Farres. \\ Portsmouth UK \\ with 10 figures and 4 tables
}

*Corresponding author

\begin{abstract}
Summary
Field evidence from the Maltese Islands is presented of extreme wave activity in the central Mediterranean Sea. An extensive range of extreme wave signatures, both erosional and depositional, is here presented for the first time and indicates a wave attack from the NE.

Existing models of runup and boulder detachment imply that the extreme wave signatures lie beyond the capabilities of storm waves. These considerations, taken together with the range of evidence available, point toward tsunami as the agency responsible, which is consistent with the evidence from Mediterranean marginal coasts opposed to the Maltese Islands. Evidence from existing boulder detachment, tsunami runup and wave velocity models suggests that tsunami with shoreline wave height of up to $\sim 4 \mathrm{~m}$, and with local velocities of $>10 \mathrm{~ms}^{-1}$ would have been required in order to form the signatures observed.
\end{abstract}

\section{Introduction}

The Maltese islands occupy a central location in the Mediterranean basin, a seismically active region with a clear potential to create tsunami, for which there is abundant historic evidence (TinTI ET AL 2004, PAPADOPOUlOS 2009). Many of the coastlines around the margins of the Mediterranean Sea possess both field evidence and direct records of high energy wave events including tsunami. Evidence from coasts directly opposed to the Maltese Islands has been described with increasing frequency in recent years and is summarised in Table 1.

The mid Mediterranean location of the Maltese Islands enables them to function as a natural recorder of maritime wave events, and it would be surprising if the above events had not affected Maltese coastlines to leave identifiable traces. Indeed direct historic records exist for Gozo and Malta of tsunami in 1693 and 1908 (Platania 1909, BARATTA 1910, CAMILLERI 2006). This paper now presents for the first time extensive field evidence of the impacts of these events in the Maltese islands, and places it in the context of the wider discussion of the debate concerning the capabilities of storm and tsunami waves.

A suite of features, both depositional and erosional, has been recognised as indicators of high energy coastal events in previous studies (BRYANT 2008, PARIS ET AL 2011, SCHEFFERS 2008). Unusual accumulations of large displaced boulders and sculpted bedrock features, hitherto unreported in the scientific literature, have been identified on shore platforms, coastal slopes and cliff tops along the east coasts of Malta. Similar forms on coastlines elsewhere have been interpreted as associated with high-energy events such as extreme storms and/or tsunami waves (PARIS ET AL 2011; SCHEFFERS, 2008). This paper presents an overview and initial interpretation of these forms, and their implications for the central Mediterranean region.

The Mediterranean context has a wider significance in that, as a sea with restricted fetch (Table 1), it has a significantly less energetic extreme wave climate in comparison with major oceans. It is not directly connected to a hurricane generating zone, nor affected by 
propagation of major swell waves away from high latitude storm belts (ENGEL \& MAY 2012). In the absence of the potentially complicating factor of oceanic storm waves and swells, the Maltese Islands offer a significant test of the competing hypotheses of storm waves versus tsunami in explaining extreme wave events at elevations of up to $>20 \mathrm{~m}$ asl, and in this context have the potential to make a significant contribution to this question (HALL ET AL 2010, SCHEFFERS ET AL 2010).

We have identified the presence, distribution and forms of extreme wave features at several sites across the Maltese Islands. It is the purpose of this paper to conduct an introductory overview, and in particular to:-

- present field evidence of extreme wave features

- identify the distribution of erosional and depositional features

- interpret them in the context of erosion, transportation and deposition processes associated with high energy wave conditions

- speculate on the nature of the event or events which formed them.

\section{Geographical Context}

The Maltese Islands are situated at approximately $36^{\circ} \mathrm{N} 14^{\circ} \mathrm{E}$, and comprise the three major islands of Malta, Gozo and Comino. The islands are composed of sedimentary strata of Oligocene and Miocene age, in which limestones predominate (PEDLEY 1978, PEDLEY \& Waugh 1976, Pedley et al 1976, Pedley et al 2002). There has been a general tilting of the Miocene formations of Malta to the NE during the post-Miocene tectonic uplift (AleXANDER 1988), subsequently dated by PEDLEY (2011) as between $5.3 \mathrm{Ma}$ and $1.8 \mathrm{Ma}$ ago. This tilting has created a topography in which cliffs tend to dominate the western coasts, whereas lowland valleys and shore platforms occur on the eastern coasts.

The Globigerina Limestone is a mainly homogeneous and massively bedded rock which generally yields large boulders. However, this unit can be sub-divided by two layers of conglomerate containing phosphoric nodules. The Coralline limestones, in contrast, are far more variable in texture and thinly bedded, commonly in beds $0.5-1 \mathrm{~m}$ thick, and well jointed. These characteristics critically define both the size and shape of boulders released into the coastal zone from these strata.

These Miocene limestones present coastal topographies ranging from vertical cliffs of $100 \mathrm{~m}$ elevation, through bedrock slopes to small coastal valleys and plains. They present varied terrains to incoming wave attack and typically form structural platforms across gently dipping limestone beds, commonly separated by scarps of $0.5-1.0 \mathrm{~m}$ on the Coralline beds, and up to $2 \mathrm{~m}$ on the Globigerina (PASKOFF \& SANLAVILLE 1978, ALEXANDER 1988).

FURLANI ET AL (2013) have shown that in historic time changes in sea level have affected coastal lands in ways that influence geomorphic interpretations of coastal deposits. They show that in Roman times sea level for sites on the east coast of Malta was at $-1.36 \mathrm{~m}$ relative to the present, and at $-0.56 \mathrm{~m}$ during the Middle Ages. This implies that any sedimentary features, including extreme wave signatures, of these ages would have been formed higher above sea level by these amounts than their current position.

The climatic drivers of the wave characteristics acting on the coastal landscapes of Malta are summarised by Chetcuti ET AL (1992), GALDIES (2011) and CAMILlERI (2012). The key climatic characteristics are wind direction and velocity in relation to available fetches. Data 
for the 30 year period 1958-1987 show that the NW sextant dominates wind duration at $30.08 \%$ per annum. The NE sextant, of particular relevance to this study, provides winds through $10.33 \%$ of the year which include the stormy Gregale wind. AGIUS (1925) provides an analysis of Gregale events for the period 1910-1920, his data showing that gales (Beaufort Scale 8: $\left.>17.9 \mathrm{~ms}^{-1}\right)$ occurred on average on 2.9 days per year $\left(\mathrm{da}^{-1}\right)$, and severe gales (Beaufort Scale 9: $\left.>22.3 \mathrm{~ms}^{-1}\right)$ on $0.36\left(\mathrm{da}^{-1}\right)$ over that 11 year period. The nomogram of CERC (1984) suggests that the maximum wind blowing across the maximum fetch in the NE aspect is capable of creating waves of up to $5.18 \mathrm{~m}$ (17 feet) in height. This is consistent with the report in AgIUs (1925) of waves, prior to the construction of the St Elmo and Ricasoli breakwaters, 'often' 18 feet (5.49 m) high penetrating into Grand Harbour, Valletta.

The Maltese islands experience a microtidal environment with tidal oscillations of no more than $0.2 \mathrm{~m}$. Seiches with amplitude of up to $1 \mathrm{~m}$ also occur (DRAGO 2008, 2009), although the extent to which these events are correlated with other sea level fluctuations is uncertain.

Whilst this analysis does identify typical storm conditions, the data available are insufficient to identify the infrequent and truly extreme conditions critical to this paper. In the absence of longterm local open water wave records to permit longterm extreme wave analysis of the Maltese waters, we refer to the regionally available data closest to NE Malta. These are acquired by the RON buoy off Catania, SE Sicily, where nearshore bed gradients are similar to those at Malta. SCICCHITANO ET AL (2007) quote a 50 year maximum storm wave of $9 \mathrm{~m}$ for this location, which, in the absence of any realistic alternative, is assumed as the closest available long term extreme estimate of breaking storm wave height is for the NE coast of Malta.

\section{Field Evidence of Extreme Event Indicators}

\subsection{Distribution}

Subaerial evidence of extreme wave occurrence is present, although not ubiquitously, at elevations of up to $\sim 22 \mathrm{~m}$ above sea level (asl) throughout the northeast flank of the island group along a coastal front some $30 \mathrm{~km}$ in length from Xwejni Bay, Gozo, via Comino, to Żonqor Point (near Marsaskala), southeast Malta (Figure 1). It is notable that although this aspect is exposed to some significant storms it faces neither the maximum fetch, to the east, nor the most frequent winds, from the west.

The extreme wave signatures are associated with a range of local topographies including low level coastal platforms (Water Park), linear rock ramparts (Qorrot, Quarry, NW Comino, Xghajra, Żonqor), and coasts of varied topography (White Tower, Comino col, Aћrax) (Table 2 ). These include both headlands and linear coastlines, embracing a range of types of coastal slope and relief, yet the signatures are absent from cliffed coastlines of $>25 \mathrm{~m}$ in elevation. In some cases human activity has encroached upon the landward edge of the features, in the form of agriculture, urbanisation, coastal defence structures and landfill, denying the opportunity to observe the original signatures at their extreme landward margin, including key features such as elevation and run-up.

The study sites span the complete range of the more resistant rock types of the Maltese Islands, the major limestone formations, which act as boulder sources. Observations of boulders themselves, and the sockets from which they were derived, indicate that thickness of individual rock units within the Coralline limestones commonly lies in the range 0.5-1.0 m. Within the Globigerina formations, the Phosphoritic Conglomerate beds commonly have a 
thickness of $\sim 0.5 \mathrm{~m}$, whereas the massively bedded limestone units are up to $2 \mathrm{~m}$ deep. The primary form of newly detached boulders from these sedimentary strata is a tabular cuboid, of which the $\mathrm{c}$ axis, representing the thickness of the rock unit, is commonly the limiting dimension.

\section{Methods}

Field investigation was carried out at three levels. A reconnaissance survey enabled the initial identification of the nature and distribution of the field evidence.

An extensive approach was then applied to identified sites, with observation of elevations and distances to shoreline of depositional and erosional signatures, and boulder characteristics.

At selected sites of outstanding interest an intensive approach was adopted, embracing GPS surveys and detailed studies of boulder populations.

Field investigation was supplemented by laboratory observations of remotely sensed imagery. Google Earth provided a perspective at site level, and images from 1:4000 aerial photography of 1967, 1993 and 2008 enabled the observation of individual features using the Stereo Analyst function in ArcGIS 10, and subsequent mapping to ERDAS Imagine 10.

Topographic mapping of the study sites was undertaken variously by field survey with a digital theodolite, supplemented by digital transformation of existing published DOS 1:2500 maps, with contours reinterpolated from the original imperial units to a metric scale. Geomorphic mapping was undertaken by locating specific geomorphic features with a combination of tape and Abney level and GPS observation, supplemented by field photography and laboratory interpretation of aerial photography and Google Earth imagery.

Boulders form a major component of the field evidence, and were described by their axial dimensions. Volume was thus computed as the product of the three axial values, to give the volume of the circumscribing rectangular prism as a first approximation. Orientation of horizontal boulders was determined by measurement of a-axis bearing. In the case of imbricate boulders, the orientation of the $a / b$ plane was observed with a field compass, and the location mapped. Standard laboratory techniques were employed to determine bulk density of rock samples, particle size analysis, and petrographic characteristics of fine grained sediment samples.

\section{Field Evidence of Extreme Event Signatures}

\subsection{Depositional Features}

5.1.1 Boulder berms and spreads: at Quarry site, Gozo, a continuous boulder berm extends for $\sim 150 \mathrm{~m}$ along a coastal rampart at $7-10 \mathrm{~m}$ asl, and intermittently for a further $400 \mathrm{~m}$ or so (Figure 1). It trends parallel to the coastline at $320^{\circ}$ (i.e. facing $50^{\circ}$ ) and overlooks a bare rock slope lacking significant clastic material. Its seaward margin, formed by an abrupt line of large boulders, roughly parallels the planform of the coastline some $42 \mathrm{~m}$ distant (Figure 2). The largest boulders have an $a$-axis length of $>4 \mathrm{~m}$, and an estimate mass of 15-40 t. Along the line of a surveyed profile (Figure 2), the spread attained a width of $24 \mathrm{~m}$, thinning upslope with declining particle size to a maximum elevation of $13.4 \mathrm{~m}$ asl; elsewhere it becomes difficult to identify its landward margin due to the intrusion of made ground. It is apparent that the boulders have been moved up a slope with a general gradient of $9-11^{\circ}$. No morphological or adherent subfossil evidence was observed to suggest a littoral or sublittoral 
origin, implying that the boulders had originated from the terrestrial surface of the coastal slope itself, where a scarp suggests itself as a likely boulder source.

On the Ahrax ridge, NE Malta, a line of large boulders abruptly fronts a boulder spread some $300 \mathrm{~m}$ in length and linear to curved in planform (Figure 3). It parallels a cliff edge at 10-20 $\mathrm{m}$ asl some $35-40 \mathrm{~m}$ from the cliff trending northwards before curving away landwards to $120 \mathrm{~m}$ distant from the coastline. At this point it lies landward of a col at $7.3 \mathrm{~m}$ asl which separates a large boulder (3983867 N, $443163.8 \mathrm{E})$ at $6.8 \mathrm{~m}$ asl from the coastline. The boulder line may be picked up again just north of the col, whence it swings back northwards toward the coastal cliffs again. Its somewhat intermittent but nevertheless clearly identifiable form broadly parallels the cliffline, with its planform indented by a funnel leading through the col, which itself lies opposite to the lowest elevation of the coastal cliffs of $2 \mathrm{~m}$. The largest boulders on the seaward front exceed $2 \mathrm{~m}$ and $1 \mathrm{~m}$ on the $a$-axis and $b$-axis respectively. Landward of the boulder front lies a diminishing scatter, $\sim 80$ metres in width, of smaller boulders, cobbles and sand feathering out towards an ill-defined landward margin.

It is evident that the marine event responsible for the deposition of this deposit washed over vertical sea cliffs of 2 to $20 \mathrm{~m}$ in height. Lying inland from the lowest cliffs is a slope concavity, which evidently funnelled onshore penetration of flow towards the col, permitting boulders to be carried up tens of metres inland prior to their deposition, and allowing incoming water to overflow the col some $80 \mathrm{~m}$ distant and enter the valley draining into Ahrax Bay. Along the coast south eastwards of the col both the cliffs and the land behind rise steadily to over 20 metres, limiting the run up of water in that sector, and limiting inland boulder transport to 35-40 metres from the clifftop. The planform of the boulder line thus reflects the topographic influence on wave runup in funnelling it over the ridge crest. The highest evidently displaced boulder observed is at an elevation of $22 \mathrm{~m}$ asl.

The source of the boulders fronting the spread merits critical consideration. Submarine contours along the cliffed coast suggest that the cliffs plunge directly to at least 5 metres beneath sea level (UK HYDROGRAPHIC OFFICE 2003), making it extremely unlikely that boulders were lifted onshore from submarine sources up a vertical cliff exceeding 7.5 metres and upwards beyond to an elevation of $>20 \mathrm{~m}$. The edge of the cliff (Figure 3) shows a rock step some $20 \mathrm{~m}$ long and up to $1 \mathrm{~m}$ deep along the cliff edge, such as would have been created by the erosion of a former cornice. This appears to be a likely source of a $\sim 75$ tonne boulder, found fractured into three adjacent masses, lying some 15-18 $\mathrm{m}$ inland (Figure 4). The erosion of such a cornice together with the presence of a field of sockets on the slope to the seaward of the boulder line itself would appear to have the potential to supply the boulders comprising the spread.

5.1.2. Individual boulders: Sometimes circumstance not only allows the mass and altitude of boulders to be determined, but it may also be possible to trace particular boulders to their individual source, sometimes in a different part of the coastal zone. The field evidence may be such that the place of origin can be precisely identified either as an outcrop of a unique lithological unit, an erosion scar which matches the shape of the boulder with either a fresh fracture face, or an identifiable disturbed morphological or ecological zone. This facilitates the evaluation of the distance and direction of transport, and any elevation or inversion by tumbling during transportation. This in turn enables interpretation of the nature of the process involved and the assailing force responsible.

5.1.3. Imbricated upright boulders: these are well displayed at two contrasting sites, Qorrot and Water Park. At the former they occur at an elevation of $>8 \mathrm{~m}$ asl, and at the latter below 1 
$\mathrm{m}$ asl. Imbricate boulders are indicative of the flow direction from which they were deposited, as indicated generally by the orientation of the long axis and more specifically by the $a / b$ plane. All the $a / b$ plane orientations lie in the range $0^{\circ}-90^{\circ}$, with $71.4 \%$ within the restricted range of $30^{\circ}-69^{\circ}$. The mean orientation is $48^{\circ}$.

\subsubsection{Split boulders: Notable examples occur at Aћrax, Xghajra and Qorrot. At Aћrax a} quasi rectangular boulder, split into three contiguous fragments, lies 15-18 m inland of a clifftop at $10 \mathrm{~m}$ asl. The reconstituted original would have a $5.4 \mathrm{~m} \mathrm{a}$-axis and an estimated mass of $\sim 75 \mathrm{t}$. It appears to have originated from a step eroded into the cornice of the nearby cliff (Figure 3). At Xghajra two buff limestone boulders, some 3.5-4.0 m apart, with congruent faces opposing each other across the gap between them, rest at $5.7 \mathrm{~m}$ asl. At Qorrot, several slab-shaped boulders of phosphoritic conglomerate lie split into two or more smaller slabs (Figure 5). These features suggest substantial and violent impact on grounding at the point of deposition, indicative of turbulent transportation and sudden reduction in flow velocity. The fact that such broken boulders remain in place implies that the event which deposited them was a most extreme event, since any subsequent removal of the diminished boulder fragments that now remain would require only a fraction of the power required to transport their original combined mass. Such features do not occur in unambiguous storm deposits adjacent to tsunami sediments, implying that split boulders may be indicative of the latter (GOTO ET AL 2010).

\subsubsection{Scarp-top boulders: At several study sites, the largest clasts present are slabs of rock} evidently detached from a local escarpment formed by the sedimentary rock which forms the local terrain. These clasts are generally tabular in shape with the $c$ axis length defined by the depth of the sedimentary stratum. They are found lying in front of the scarp, banked up against it or, more tellingly, lifted up and deposited on the top of the scarp-forming rock from which they are derived. Such boulders are frequently the largest clasts present at each site, for they represent the product of primary fracture of the scarp forming rock, and may be as large as $100 \mathrm{t}$ in the case of the more massive Globigerina limestone. Transportation appears to cause these unstable shapes to fracture into successively smaller fragments which may be subsequently transported further inland.

Boulders of this category sit atop the escarpment from which they have been eroded, and offer the opportunity to evaluate the forces involved in their detachment, removal entrainment and uplift. The common occurrence of gently seaward dipping resistant limestone beds within both Upper and Lower Coralline formations provides numerous examples of this phenomenon and opportunities for the analysis of the forces and processes involved. Scarps were observed at Armier, Qorrot, Xghajra and Żonqor, ranging between 0.5 and $1.6 \mathrm{~m}$ in height, according to the thickness of the defining beds.

Indicative lithology, where present, may enable the point of origin of displaced boulders to be identified, and thus the point of application of the assailing force which detached and transported them. At Qorrot site (Figure 5) a distinctive bed of phosphoritic conglomerate, $0.5 \mathrm{~m}$ thick and with its base at altitudes of 7.1-8.6 m asl, sits within the Globigerina Limestone. Tabular masses of this conglomerate are seen broken off from the $0.5 \mathrm{~m}$ deep scarplet created by the bed which they form. Some of these masses lie against the scarp as if in the process of surmounting it, whilst a considerable spread of conglomerate masses lies scattered atop the bed and further upslope. Significantly they are lacking downslope of the scarp. The larger erratics are commonly in the range of 3-4 tonnes, with the largest measured at 8.5 tonnes, and they extend upslope from the scarp to maximum altitudes of 11.4 and 12.6 
$\mathrm{m}$ asl respectively. Their current distribution indicates movement exclusively onshore from their point of origin at the scarp edge. The significance of the Qorrot site is that it demonstrates that an assailing force sufficient to detach, entrain and elevate tabular boulders was applied at altitudes of 7.1-8.6 m asl, and that it was sufficiently powerful to carry them up $15^{\circ}$ slopes to altitudes $\sim 4 \mathrm{~m}$ higher (Figure 6 ).

\subsubsection{Subfossil-encrusted boulders: Where adherent subfossil bioforms of littoral and} sublittoral species occur on boulders, the zone from which the boulders originated can be identified. In a minimally tidal environment such as Malta, this points significantly to erosion at or below mean sea level, and may be used to estimate the distance travelled, the height through which the boulder has been elevated and, with appropriate dating, the timing of the extreme event responsible.

The identification of the origin of such boulders requires the identification of the assemblage of encrusting organisms and their environmental preferences. These are present at several sites. At Comino Col (Figure 1) a boulder of $\sim 1$ tonnes mass and covered with serpulid and vermetid worm casts and scleractinian corals (provisionally identified as Caryophillia species) is found at an elevation of $\sim 9 \mathrm{~m}$ at $36.01976^{\circ} \mathrm{N}, 14.33857^{\circ} \mathrm{E}$, some $42 \mathrm{~m}$ from the waterline. The bioforms indicate a boulder source at least $1 \mathrm{~m}$ and possibly as low as $20 \mathrm{~m}$ below sea level. The agent responsible for the transportation of this boulder was evidently capable of erosion from a sublittoral level, and of transporting a 2 tonne boulder upwards across an extremely rough subaerial rock slope of $13^{\circ}$ through a vertical elevation of at least $10 \mathrm{~m}$.

At Xghajra subfossil lithophage borers are present on a boulder at $6.1 \mathrm{~m}$ asl some $36 \mathrm{~m}$ from the shoreline. The boulder is tabular in form, of dimensions $3.4 \times 2.3 \times 1.1 \mathrm{~m}$ and apparently right way up. Its mass is estimated at 19.5 tonnes. It has evidently been driven onshore, being rafted up the sloping platform and lifted up a nearby $1 \mathrm{~m}$ vertical scarp to its current position. The presence of the infralittoral species Petricola lithophaga indicates that this boulder originated from below sea level. At Water Park site the subfossil assemblage encrusting boulders includes serpulids and polychaetes, indicative of an infralittoral or sublittoral origin.

5.1.7. Sand sheets: sediment sheets at the land surface have been found at three sites, although not exclusively composed of sand. Although the fines in these sediments are dominated by sand, and material of finer grade is lacking, there may also be a substantial component of granules and gravel.

At White Tower a spread of surface sediment runs northeast for some $140 \mathrm{~m}$ from the landward side of the cluster of megaclasts at the tip of the headland, in a swathe some $5-10 \mathrm{~m}$ wide and at a distance of $30-50 \mathrm{~m}$ from the shoreline at an elevation of up to $\sim 6 \mathrm{~m}$ asl. Analysis of the fine fraction $(<2 \mathrm{~mm})$ of two samples of this deposit shows that $>90 \%$ exceeds $1 \mathrm{~mm}$, with a negligible amount of medium and fine sand. The sediment comprises a substantial proportion of shell fragments, including some in the $2-4 \mathrm{~mm}$ range, in addition to subrounded particles of limestone.

At Ahrax, sandy sediments lie in the zone of deposition associated with the boulder spread. To the seaward side they are present in solution basins within the exposed fretted surface of limestone highly weathered in this hostile coastal weathering environment. Landward of the main boulder spread the sandy deposit appears more continuous, but thinning gradually to a 
limit about some 40 metres inland of the boulder line, draped across the crest of the ridge and ranging in elevation from $8-22 \mathrm{~m}$ asl. Analysis of the fine fraction shows coarse/medium sand with a mode retained on the $250 \mu$ sieve, very close to the particle size distribution of contemporary beach sand at nearby Armier Bay.

The predominant characteristics of these sediments overall are the coarseness of the sand, the inclusion of fragmented shelly material, the apparent polish of the shell fragments and the subrounded particle shapes.

5.1.8. Dump deposits (BRYANT 2008): a deposit with these characteristics lies contiguous with and downslope of the berm ridge at Comino Col, over an area of several hundred square metres.

\subsection{Erosional Features}

5.2.1. Scoured bedrock terrains: Water flows of high energy, with flow velocities of $>10 \mathrm{~ms}^{-1}$ and especially when associated with jets and vortices within turbulent flow, are capable of direct erosion of bedrock (BRYANT 2008). At the northernmost headlands of both Malta (Ahrax) and Comino (Ghemieri), small scale scoured terrains are present at 6-14 $\mathrm{m}$ asl. Irregular pinnacles and mounds, scoured hollows and unconnected channels form spatially chaotic terrains in the local bedrock surface with local relief of $0.5-1 \mathrm{~m}$. These exposed rocky headlands are the sites most exposed to an extreme wave attack from the NE. BRYANT (2008) suggests such forms to be characteristic of rocky headlands which have disturbed the flow of an advancing tsunami wave (Figure 7).

5.2.2. Eroded scarps: These features are widely characteristic of Maltese sites where quasi horizontal limestone beds form the coastal terrains. At Ahrax Point, for example, a series of clear-cut scarps is present on the nose of the headland at elevations of 6-12 $\mathrm{m}$, the largest one being up to $2.5 \mathrm{~m}$ high. The absence of an accumulation of fallen debris at the scarp foot suggests that, in lacking an agent of transportation for its removal these are not normal subaerial scarps. The scarps are located on exposed headland sites, where the exposed edges of the sedimentary beds lie parallel to the passing waters and are thus exposed to the maximum lateral shearing forces. They are, in addition, associated with the scoured bedrock terrains.

5.2.3. Sockets: These features are quasi circular vertical-sided cylindrical hollows formed on bedrock surfaces and cutting transverse to bedding structures. They are clearly erosional features and are interpreted as sockets from which slabs of rock have been removed by cavitation-induced plucking (Figure 8). In this study they have been observed at five sites, on outcrops of both Upper Coralline and Lower Coralline Limestone, at elevations of up to $11 \mathrm{~m}$ asl.

The distribution of erosional features in relation to topography, coastal exposure and direction of wave approach is shown in the map of the Ahrax site (Figure 3). The geography of the coastline is such that extreme waves approaching from an azimuth of $50^{\circ}$ would have swept up the ridge opposed to it, passing through a col at $\sim 7 \mathrm{~m}$ asl and overflowing into the valley beyond, where it would have met with water having rounded the headland and coming up from a bay to form a turbulent confluence on the landward flank of the ridge. Concentrations of sockets are also present at 6-10 $\mathrm{m}$ on the coastal rock rampart directly opposed to an extreme wave approaching form the NE, and also where such a wave would 
have passed over the crest of the coastal headland. Two further socket fields are present, one in the base of the valley where the runup would have had a maximum velocity, and a linear field along the east flank of the valley in the zone of confluence. All of these sites represent locations where the flow pattern of the extreme wave may have been likely to cause stress maxima on the underlying rock surface. The distribution of the erosional and depositional evidence thus forms a coherent spatial pattern, which can be readily interpreted in terms of the characteristics of the event which formed them.

This brief overview of field evidence clearly reveals the presence in Malta of a substantial range of erosional and deposition features associated by previous authors with extreme wave events.

\subsection{Patterns of erosion and deposition}

The spatial pattern of evidence along the northeast flank of the Maltese Islands strongly suggests that the assailing force responsible for them approached from the northeast, an inference strongly supported by the orientation of the upright imbricate boulders.

These varying topographies of the study sites permit between-site comparisons of patterns of erosion and deposition. Figure 9 shows the altitudinal distribution of selected extreme event indicators at the study sites. A notable feature is the variation in the maximum height of deposition between sites. At Water Park urbanisation of the backshore accounts for the absence of natural terrain at elevations above $2 \mathrm{~m}$ asl. It is possible that at Xghajra and Żonqor higher deposits exist than those observed at 7 to $8 \mathrm{~m}$ asl but are now also obscured by backshore modification of human origin. At the remaining sites, however, the highest deposits range from 11 up to $>22 \mathrm{~m}$ asl. It is perhaps notable that the coastlines at Qorrot and Quarry are formed by long unbroken bedrock ramparts, with very limited scope for any lateral diversion of an incoming water mass, constraining it to pile up against the rampart. The greatest elevations of deposition occur at Comino col and Ahrax, with deposits up to 16.5 and $>22 \mathrm{~m}$ asl respectively. These occur where the elevated headlands are exposed fully to the NE and create diversion and funnelling of flow.

Patterns of erosion are equally instructive. The majority of study sites reveal zones of erosion between sea level and 4-8 asl, unsurprising because these terrains fall in part within the reach of storm waves. More indicative, however, is the Qorrot site, where the zone of erosion is clearly shown by lithology to lie between 7 and $8.5 \mathrm{~m}$, well above the breakpoint of storm waves. At Ahrax the evidence suggests that the high level boulders have been derived by water overriding cliffs and detaching boulders which formed the clifftop cornice. At 6 of 11 sites bioform-encrusted boulders, derived from sea level or below, are present at up to $9 \mathrm{~m}$ asl, indicating that they have been eroded from sublittoral sources and subsequently carried up to these altitudes.

\section{Discussion}

\subsection{Boulders}

6.1.1. Highest boulders: these provide an indication of the elevation attained by runup of historic high energy events. This study has revealed boulders deposited at different sites by extreme coastal events at up to $22 \mathrm{~m}$ asl (Ahrax), $17 \mathrm{~m}$ asl (Comino col), $13 \mathrm{~m}$ asl (Quarry) and $12 \mathrm{~m}$ asl (Qorrot). Other such deposits occur at much lower altitudes right down to sea level (Armier Point, Water Park, White Tower) and some have undoubtedly been encroached 
upon by human activity at their landward margins (Xghajra, Quarry, Zonqor). The varied coastal topographies of the Maltese Islands capture and preserve evidence of extreme event deposition at a range of elevations. As large boulders require considerable tractive force in order to be moved, their presence implies a significant depth and velocity of the depositing flow. They thus provide only a minimum estimate of the true height of run-up of the flow.

6.1.2. Largest boulders: these are indicative of the force, and therefore the flow velocity, required in order to detach large particles during an historic erosional event. The model of NANDASENA ET AL (2011) is later used to provide a minimum estimate of the force available during the event, and may therefore provide insights into the magnitude of the event responsible for their deposition (see Section 6.2).

6.1.3. Imbricate boulders: Imbricate boulders are indicative of the direction of the flow from which they were deposited. Imbrication also denotes a high flow velocity in the onshore direction, sufficient to transport large boulders. These are widespread through the sites in this study, and were specifically observed at two sites of contrasting elevation, namely Qorrot and Water Park. Although they exhibit a range of local azimuths throughout the whole NE quadrant, the strong median around $\mathrm{N} 50^{\circ} \mathrm{E}$ is strongly indicative of the vector of the agent of deposition. Where not imbricated, boulders are often aligned with their a-axis normal to maximum flow, also suggesting a flow broadly from the NE.

\subsection{Tsunami or storm waves?}

In interpreting the cause of extreme wave events, there are two feasible hypotheses, namely tsunami waves or storm waves. The former are long period waves (up to $10^{2}$ minutes) of long wavelength $(>100 \mathrm{~km})$, the latter characterised by much shorter period (max. $20 \mathrm{secs}$.) and length $\left(\sim 10^{2} \mathrm{~m}\right)$. On account of their long wavelength tsunami waves possess a factor of $4 \mathrm{x}$ greater power in relation to their height than storm waves. This greater power enables tsunami to achieve both detachment of significantly larger bedrock clasts and much also greater run-up heights and distances.

The types of field evidence described above have been variously ascribed to the effects of sea waves or tsunami, and all are consistent with tsunami activity. There appears to be no single feature widely regarded as definitively diagnostic of tsunami activity, although BRYANT (2008) suggests that scoured terrains on headlands at elevations beyond the reach of storm waves may be a definitive tsunami signature.

There is, in particular, a problem of overlap between the boulder detaching capacities of storm and tsunami waves, especially at low to moderate elevations above sea level with moderately sized boulders, where both mechanisms may be capable of providing a feasible explanation. However, extreme values of both size of transported boulders and runup may enable discrimination between the two potential mechanisms if the field evidence lies beyond the capacities of likely maximum storm waves.

A first approach to this issue is to test the likely formation of the coarse boulder sediments with equations which model boulder detachment by waves. The equations of NANDASENA ET AL (2011), refining the approach of NOTT (2003), were employed with a view to discriminating between tsunami and storm waves.

Appropriate data are available for two shoreline boulder fields, White Tower and Water Park, where respectively 127 and 31 boulders with a $b$-axis $>1 \mathrm{~m}$ were observed. Boulders were 
classified according to whether their form suggested a pre transport setting on a sublittoral plane bedrock surface (Type 1) or lying on a detached from a scarp platform edge subaerial (Type 2) or sublittoral plane surface joint bounded on five faces (Type 3). The appropriate Nandasena equation was applied in each case, as follows:

Platform

$$
\begin{array}{ll}
\mathrm{H}_{\mathrm{t}} \geq 0.5 \mathrm{c}\left[\rho_{\mathrm{s}} / \rho_{\mathrm{w}}-1\right][\cos \theta+(\mathrm{c} / \mathrm{b}) \sin \theta] / \mathrm{C}_{\mathrm{d}}\left(\mathrm{c}^{2} / \mathrm{b}^{2}\right)+\mathrm{C}_{1} & \text { Equation 1 } \\
\mathrm{H}_{\mathrm{s}} \geq 2 \mathrm{c}\left[\rho_{\mathrm{s}} / \rho_{\mathrm{w}}-1\right][\cos \theta+(\mathrm{c} / \mathrm{b}) \sin \theta] / \mathrm{C}_{\mathrm{d}}\left(\mathrm{c}^{2} / \mathrm{b}^{2}\right)+\mathrm{C}_{1} \quad \text { Equation 2 }
\end{array}
$$

Equations $1 \& 2$ based on Nandasena et al (2011) Eqn.10.

Jointbound

$$
\begin{array}{ll}
\left.\mathrm{H}_{\mathrm{t}} \geq 0.25 \mathrm{c}\left[\rho_{\mathrm{s} /} \rho_{\mathrm{w}}-1\right)\right]\left[\cos \theta+\mu_{\mathrm{s}} \sin \theta\right] \mathrm{C}_{\mathrm{l}}^{-1} & \text { Equation } 3 \\
\mathrm{H}_{\mathrm{s}} \geq \mathrm{c}\left[\left(\rho_{\mathrm{s} /} \rho_{\mathrm{w}}-1\right)\right]\left[\cos \theta+\mu_{\mathrm{s}} \sin \theta\right] \mathrm{C}_{1}^{-1} & \text { Equation } 4
\end{array}
$$

Equations $3 \& 4$ based on Nandasena et al (2011) Eqn. 20.

Where $\quad \begin{aligned} & \mathrm{H}_{\mathrm{t}}=\text { tsunami wave height }(\mathrm{m}) \\ & \mathrm{H}_{\mathrm{s}}=\text { breaking storm wave height }(\mathrm{m}) \\ & \mathrm{C}_{\mathrm{d}}=\text { coefficient of drag, typically } 1.95 \\ & \mathrm{C}_{\mathrm{l}}=\text { coefficient of lift, typically } 0.178 \\ & \rho_{\mathrm{s}}=\text { density of boulder } \\ & \rho_{\mathrm{w}}=\text { density of seawater } \\ & \mu_{\mathrm{s}}=\text { coefficient of static friction, estimated as } 0.7 \\ & \mathrm{~b}=\text { b-axis length } \\ & \mathrm{c}=\text { c-axis length } \\ & \theta=\text { slope gradient }\end{aligned}$

Results show that removal of the boulders could have been accomplished at both sites by tsunami waves with minimum height up to $4.5 \mathrm{~m}$, whereas storm waves of up to at least $18 \mathrm{~m}$ would have been necessary to accomplish the same work (Table 3). It is shown in Figure 10 that that 20 of 127 of the boulders observed at White Tower and 9 of 31 of those at Water Park, an overall mean of $18.4 \%$, exceed the capability of the postulated maximum storm wave height of $9 \mathrm{~m}$ (SCICCHITANO ET AL 2007). This analysis points toward tsunami as the most likely force available at this location with the capacity to detach and transport the largest boulders at these sites.

A second approach to this issue is to apply existing models of tsunami capability to the Maltese field data in order to retrodict the magnitude of tsunami waves required to achieve the runup heights implied by the field evidence. These are employed here only in those cases where the field evidence of the maximum elevation of extreme wave deposits is not obviously obscured by backshore development. Furthermore, as FRYER (2011) points out, the feather edge of tsunami wave deposits at maximum inundation level may be ephemeral and leave negligible permanent trace. As such it is stressed that the calculated values, based on maximum observed elevation of deposits, can only provide a minimum value of runup height. BRYANT (2008) provides theoretical models (from SYNOLAKIS 1987, 1991 and TADEPALLI \& SYNOLAKIS 1994) for approximating the runup height of tsunami waves. A solitary tsunami wave is modelled by Equation 5:- 
$H_{t}=\left(\frac{H_{r \max }}{2.83(\cot \beta)^{0.5}}\right)^{0.8}$

Equation 5, rearranged from BRYANT (2008) Equation 2.11.

where $H_{\text {rmax }}=$ maximum observed height of tsunami sediments above sea level (m)

$H_{t}=$ wave height at shoreline $(\mathrm{m})$

$\beta=$ slope of seabed (degrees)

In reality, however, some $70 \%$ of tsunami waves are $\mathrm{N}$-waves, which are modelled by Equation 6:-

$H_{t}=\left(\frac{H_{r \max }}{3.86(\cot \beta)^{0.5}}\right)^{0.8}$

Equation 6, rearranged from BRYANT (2008) Equation 2.12.

Retrodicted tsunami wave heights at shoreline are presented in Table 4. They are greatest around Ahrax Point. Here a vertical sea cliff extends from $5 \mathrm{~m}$ asl to at least $-20 \mathrm{~m}$ at the northeast corner of the promontory, with a steep submarine gradient off the northernmost point, and lesser gradients around the flanks of the ridge. Several observations capture these variations around the promontory, with values for solitary waves ranging from 2.47-3.83 m and single $\mathrm{N}$-waves respectively $22 \%$ lower. Comino col, a similar rocky headland with a relatively steep offshore gradient shows a maximum tsunami wave height of $1.56 \mathrm{~m}$, whilst the less exposed sites show solitary wave heights of $0.89-1.55 \mathrm{~m}$, with correspondingly lower values for the $\mathrm{N}$-waves.

Wave velocity is a parameter strongly indicative of wave power and the capacity of a wave to do geomorphic work. As the wave climbs onshore its mean velocity can be similarly estimated (Equation 7), again calculated both for $H_{\mathrm{t}}$ values of both solitary and $\mathrm{N}$-wave cases.

$v_{r}=2\left(g H_{t}\right)^{0.5} \quad$ Equation 7: BRYANT (2008) Equation 2.16.

$\mathrm{v}_{\mathrm{r}}=$ mean run-up velocity at shoreline $\left(\mathrm{ms}^{-1}\right)$

$\mathrm{g}=$ gravitational acceleration $\left(\mathrm{ms}^{-2}\right)$

$H_{t}=$ depth of water flow over land (m).

Values around and approaching $10 \mathrm{~ms}^{-1}$, the minimum threshold velocity for direct erosion of bedrock, are calculated for the headland sites at A hrax and Comino col. Over rough terrain these mean flow velocity values will be accelerated locally by a range of mechanisms such as cavitation, jetting, flow reattachment and vortex formation, creating velocities with clear potential for bedrock erosion. It is precisely at such headland sites that erosionally sculptured rock surfaces are reported in this study.

It follows from FURLANI ET AL (2013) that these calculations of tsunami height and shoreline velocity based on runup altitudes should be further regarded as underestimates on account of the additional factor of recent post deposition sea level rise.

\section{Conclusion}

This paper offers new evidence, from a varied range of local settings, of high energy wave events in the central Mediterranean environment of the Maltese Islands. The evidence extends up to an altitude of $22 \mathrm{~m}$ asl. The majority of the sites themselves face NE, and the 
direction of the extreme wave attack as shown by the imbrications and orientations of tabular boulders is also from the NE.

The extreme wave boulder deposits, however, have a general freshness of form which suggests that they are not of great age. SCICCHITANO ET AL (2007), BARBANO ET AL (2010) and BIOLCHI ET AL (2013) have obtained radiocarbon dates indicating age of death for adherent bioforms on boulders in Sicily and Malta ranging from AD 800 to the twentieth century AD. Although SCICCHITANO ET AL (2007) and BARBANO ET AL (2010) link the Sicilian deposits to historical tsunami recorded in 1169 and 1693 it remains uncertain whether the Maltese deposits can be similarly attributed, or whether they could be associated with the AD 365 Crete event (POLONIA ET AL 2013). There is no evidence at present that other similar deposits predate historic time, although it is possible that a mid Holocene age cannot be ruled out.

The evidence presented includes a wide range of depositional and erosional features which are regarded in existing literature as signatures of tsunami activity. Although there is no single characteristic which can be regarded as absolutely diagnostic, we postulate that the evidence here presented cumulatively supports an interpretation of tsunami wave activity. In fact there is considerable overlap between storm and tsunami waves and discrimination currently relies upon judgements based on evidence collectively as follows:-

- the consistency of aspect of coastlines bearing extreme wave deposits, coincident with the widespread supporting evidence of imbricated boulder orientations.

- the coastlines bearing the extreme wave signatures do not directly face prevailing storm winds, and boulder orientations do not match maximum storm wave fetch, implying that storm waves are not the principal agency responsible for the observed signatures.

- the sensitive relationship between maximum runup and local topography and bathymetry is characteristic of tsunami waves.

- the altitude at which marine erosion of bedrock can be shown to have occurred, extending upwards to $>10 \mathrm{~m}$ asl.

- the absolute altitude, at $22 \mathrm{~m}$ asl, and distances, commonly up to $60 \mathrm{~m}$ and exceptionally up to $120 \mathrm{~m}$, attained by marine deposition.

- a significant proportion of large boulders onshore exceed the capacity of storm waves to detach them, according to the criteria of NANDASENA ET AL (2011), whilst the presence of boulders fractured during deposition is suggested by GOTO ET AL (2010) as characteristic of tsunami deposits.

- the onshore presence of boulders up to $\sim 9 \mathrm{~m}$ asl derived from a sublittoral pretransport setting is consistent with erosion from below sea level by $\mathrm{N}$-type tsunami waves following an initial drawback

- the patterns of erosional and depositional signatures are indicative of overwashing of coastal landscape by a high velocity sheet flow. 
A particular point of contrast between the evidence presented here and previous work is that megaclasts of multimetric dimensions and exceeding 20 tonnes such as found by previous authors in tsunamigenic and other extreme coastal environments are limited in number in Malta, and restricted to Globigerina terrains. The coralline limestones, more abundant in lowland coastal terrains, tend to fracture into clasts of metric rather than multimetric size. The sparse occurrence of massively jointed rocks in Malta, therefore, limits the size of primary clasts available for entrainment and may lead to underestimates of the magnitude of waves that deposited them.

Existing models of tsunami run-up and boulder detachment capability suggest that N-type tsunami waves of up to a minimum of $3 \mathrm{~m}$ and, exceptionally in the case of boulder transportation, a minimum of $4 \mathrm{~m}$ would be sufficient to produce the extreme wave features described in this paper.

In this fetch-limited context, the potential magnitude of storm waves is itself also strongly constrained, in contrast to the oceanic fetches affecting the coastal margins of the North Atlantic and Pacific oceans. Accordingly the overlap between tsunami and storm waves on Maltese coasts is interpreted as limited by a potential maximum storm wave height of $9 \mathrm{~m}$. Any signatures above that limit are interpreted as exceeding the likely maximum competence of Mediterranean storm waves, strongly suggesting that the most extreme waves evidenced here were palaeotsunami.

The postulation that the features described in this paper represent tsunami signatures should be viewed in the context of a Mediterranean Sea with a well recorded tsunamigenic history (SOLOVIEV ET AL 2000, TINTI ET AL 2004). There are specific records of historic tsunami in Malta in 1693 and 1908. The former is recorded in qualitative terms not conducive to yielding scientifically helpful information. The 1693 tsunami, however, is modelled for Syracuse some $150 \mathrm{~km}$ to the north at a wave height of $6 \mathrm{~m}$, suggesting that it was a large event PiatANESI \& TinTi (1998). The 1908 event yields the only precise information, a tide gauge record showing a maximum tsunami wave height of $0.91 \mathrm{~m}$, a value whose veracity may be diminished by its location within the shelter of the Valletta breakwater. Alternatively, tsunami wave heights derived by simulation modelling of hypothetical earthquakes in several Mediterranean seismic regions show wave heights for Malta ranging from 0.15-1 m (TINTI ET AL 2005), whilst PARESCHI ET AL (2006) model a tsunami crest height for 5-10 m for Malta created by a debris avalanche on Mt. Etna $\sim 8 \mathrm{k}$ BP.

Runup values are recorded for the 1908 tsunami for a few villages in Malta with an estimated maximum of 3-4 m asl at Marsaxlokk, and for many sites in Sicily close to the epicentre where they range up to $12 \mathrm{~m}$ asl. The field sites in this study, however, in uninhabited and somewhat remote areas, do not feature in such records and it is clear that the fragmentary evidence of historical tsunami wave height and runup does not provide a full picture of tsunami events in Malta, though the broader regional picture suggests that wave heights of 5$6 \mathrm{~m}$ are feasible. No clear picture currently emerges of tsunami magnitude and frequency for Malta, though CAMILLERI $(2006,2012)$ cites the return period for $4 \mathrm{~m}$ and $7 \mathrm{~m}$ tsunami waves as 600 and 1500 years respectively. Future work will be directed to identifying whether one or more events are represented here, and obtaining evidence to enable the observed signatures to be placed in historical context.

The recognition of historic tsunami waves reaching elevations of up to $22 \mathrm{~m}$ also has significant implications for public safety and coastal defence and management in Malta. Exposure to tsunami approaching from the NE or E coincides with the most densely 
populated shorelines of the Maltese islands. Extensive resort frontages, adjoining urban residential areas and a water desalination plant would be at risk of potential inundation by an event comparable in size to those inferred from the evidence presented in this paper. The most likely potential sources lie in earthquakes within the Malta Escarpment of SE Sicily some $120 \mathrm{~km}$ to the NE of Malta, and perhaps also the Western Hellenic arc (TINTI ET AL 2005). Any tsunami generated could propagate to Malta within 30 minutes (Malta Escarpment) or 70-80 minutes (Western Hellenic Arc), allowing little time for effective detection, forecasting and warning. Other possible management solutions would include public education to help shorefront residents and visitors to identify and react to signs of impending tsunami.

Alongside these measures a longterm programme of wave monitoring is required in order to gain extended wave data from which an improved definition of the extreme wave climate may be obtained, thereby facilitating improved capability to discriminate between extreme storm wave phenomena and tsunami.

\section{Acknowledgements}

Field support: Alastair Pearson, Martin Schaefer, Linley Hastewell, Ritienne Gauci, Julian Evans; Geological advice: Graham Wilson, Martyn Pedley; Cartography: Bill Johnson; Technical support: Paul Carter; Maltese advice: Darren Bianco, Robert Cachia, John Schembri, Frank Ventura, Charles Galdies, Joe Bianco, Antony Caruana; Financial support: Department of Geography, University of Portsmouth.

Address of authors: Department of Geography, University of Portsmouth, Buckingham Building, Lion Terrace, PORTSMOUTH, Hampshire, UK. PO1 3HE.

\section{References}

AgIUS, T. (1925): The Gregale. -Archivum Melitense 4.4, 139-153.

ALEXANDER, D. (1988): A review of the physical geography of Malta and its significance for tectonic geomorphology. -Quaternary Science Reviews 7, 41-53.

BARATTA, M. (1910): La catastrofe sismica calabro-Messinese (28 Dicembre 1908). -Relazione alla Società Geografica Italiana, Roma, 426 pp.

Barbano, M.S., De Martini, P.M., Pantosti, D., Smedile, A., Del Carlo, P., Gerardi, F., GUARNIERI, P., PIRROTTA, C. (2009 a): In search of Tsunami Deposits along the Eastern coast of Sicily (Italy): the state of the art. In: GUARNIERI, P. (ed.), Recent Progress on Earthquake Geology. -Nova Science Publishers, New York, 109-146.

Barbano, M.S. De Martini, P.M. Gerardi, F. Pirrotta, C. Smedile, A. Pinzi, S. (2009 b): Identification of tsunami deposits in south-eastern Sicily: Evidence of the 365 AD Crete earthquake? Gruppo Nazionale Geofisica della Terra Solida, Italy, Proceedings, 27th National Congress, Trieste, 6-8 October 2009, Sessione 1.1, 83-86.

http://www.earth-prints.org/bitstream/2122/5508/1/Barbanoetal_GNGTS_09.pdf (accessed 09.11.12).

BARbano. M.S, PirRotTA, C., GERARDi, F. (2010): Large boulders along the south-eastern Ionian coast of Sicily: Storm or tsunami deposits? -Marine Geology 275 (1-4): 140-154. 
BARbano, M.S., Gerardi, F., PirRotTA, C. (2011): Differentiation between boulders deposited by tsunamis and storm waves along the south-eastern Ionian coast of Sicily (Italy). - Bollettino di Geofisica Teorica ed Applicata 52.4: 707-728.

Biolchi, S., Furlani, S., Antonioli, F., Scicchitano, G., Cucchi, F., DraP, P., Gambin,T., Devoto, S., SALIBA, D. (2013): Large boulders accumulation along the NE Maltese coast: storm waves or tsunami event? In $8^{\text {th }}$ International Conference on Geomorphology (AIG): Abstracts Volume: 259.

Bruins, H.J., Macgillivray, A., Synolakis, C.E., BenJamini, C., Keller, J., Kisch, H.J., KLÜGEL, A., VAN DER Plicht, J. (2008): Geoarchaeological tsunami deposits at Palaikastro (Crete) and the Late Minoan IA eruption of Santorini. -Journal of Archaeological Science 35: 191-212.

BRyant, E. (2008) Tsunami - the underrated hazard. - Praxis Publishing, Chichester, 330 pp.

CAMILLERI, D.H. (2006): Tsunami construction risks in the Mediterranean - outlining

Malta's scenario. -Disaster Prevention and Management 15.1, 146-162.

CAMILLERI, D.H. (2012): Tsunami and wind-driven wave forces in the Mediterranean Sea. -Maritime Engineering 165 MA 2, 65-79.

CERC (1984): Shore Protection manual.- U.S.Army Corps of Engineers, Waterways Experimental Station, Coastal Engineering Research Center, Volumes I and II, Superintendent of Documents, Washington, D.C.

Chetcuti, D., Buhagiar, A., Schembri, P.J., Ventura, F. (1992): The climate of the Maltese Islands: A review. -University Press, Malta, 108 pp.

De Martini, P.M., Barbano, M.S., Smedile, A., Gerardi, F., Pantosti, D., Del Carlo, P., PirRotTA, C. (2010): A unique 4000 year long geological record of multiple tsunami inundations in the Augusta Bay (eastern Sicily, Italy). -Marine Geology 276, 42-57.

DRAGO, A. (2008): Numerical modelling of coastal seiches in Malta. -Physics and Chemistry of the Earth 33, 260-275.

DRAGO, A. (2009): Sea level variability and the 'Milghuba' seiche oscillations in the northern coast of Malta, Central Mediterranean. -Physics and Chemistry of the Earth 34, 948-970.

ENGEL, M., MAY, S.M. (2012): Bonaire's boulder fields revisited: evidence for Holocene tsunami impact on the Leeward Antilles. -Quaternary Science Reviews. doi:10.1016/j.quascirev.2011.12.011.

FrÉBOURG, G., HASLER, C-A., DAVAUd, E. (2010): Catastrophic event recorded among Holocene eolianites (Sidi Salem Formation, SE Tunisia). -Sedimentary Geology 224, 38-48.

FRYER, G.J. (2011): Walk the inundation limit: A suggestion for future post-tsunami surveys. -Earth Science Reviews 107, 123-127.

Furlani, S., Antonioli, F., Biolchi, S., GAmbin, T., GAuci, R., Lo Presti, V., AnZIDEI, M., Devoto, S., PALOMBo, M., Sulli, A. (2013): Holocene sea level change in Malta. Quaternary International 288, 146-157.

GALDIES, C. (2011): The Climate of Malta: statistics, trends and analysis 1951-2010. - National Statistics Office, Malta. 
Goto, K., KaWANA, T., IMAMURA, F. 2010. Historical and geological evidence of boulders deposited by tsunamis, southern Ryukyu Islands, Japan. Earth Science Reviews 102, 77-99.

HALL, A.M., HANSOM, J.D., WiLLIAMS, D.W. (2010): Wave-emplaced coarse debris and megaclasts in Ireland and Scotland: boulder transport in a high-energy littoral environment: a discussion. -J. Geology 118, 699-704.

Maouche, S., Morhange, C., Meghraoui, M. (2009): Large boulder accumulation on the Algerian coast evidence tsunami events in the western Mediterranean. -Marine Geology 262, 96-104.

MAY, S.M., WILLERSHÄUSER, T., VÖTT, A. (2010): Boulder transport by high-energy wave events at Cap Bon (NE Tunisia).-In: K.Schwarzer, K.Schrottke, K.Stattegger (eds.): From Brazil to ThailandNew Results in Coastal Research: Coastline Reports 16: 1-10. ISSN 0928-2734, ISBN 978-39811839-9-3.

NANDASEnA, N.A.K., PARIS, R., TANAKA, N. (2011): Reassessment of hydrodynamic equations: Minimum flow velocity to initiate boulder transport by high energy events (storms, tsunamis).-Marine Geology 281, 70-84.

NotT, J. (2003): Waves, coastal boulder deposits and the importance of the pre-transport setting. Earth \& Planetary Science Letters 210, 269-276.

PAPAdOPOUlos, G. (2009): Tsunamis. In: J.C. Woodward (ed.): The Physical Geography of the Mediterranean: 483-512; Oxford University Press.

PAReschi, M.T., Boschi, E., FAVALLi, M. (2006): Lost tsunami. Geophysical Research Letters 33, L22608, doi: 10.1029/2006GL027790.

PARIS, R., NAYLOR, L.A., STEPHENSON, W.J. (2011): Boulders as a signature of storms on rock coasts. -Marine Geology 283, 1-11.

PASKOFF, R., SANLAVILLE, P. (1978): Observations géomorphologiques sur les côtes de l'archipel Maltais. -Zeitschrift für Geomorphologie 22, 310-328.

PEDLEY, H.M. (1978): A new lithostratigraphical and palaeoenvironmental interpretation for the coralline limestone formations (Miocene) of the Maltese Islands. -Overseas Geology and Mineral Resources 54, Institute of Geological Sciences, HMSO, London.

Pedley, M. (2011): The Calabrian Stage, Pleistocene highstand in Malta: a new marker for unravelling the Late Neogene and Quaternary history of the islands.- Journal of the Geological Society, London, 168, 913-925. doi: 10.1144/0016-76492010-080.

Pedley, H.M., House, M.R., Waugh, B. (1976): The Geology of Malta and Gozo. -Proceedings Geological Association 87.3, 325-341.

Pedley, H.M, Waugh, B. 1976. Easter Field Meeting to the Maltese Islands, 7-14 April 1974. Proceedings Geological Association 87.3, 343-385.

Pedley, M., Clarke, M.H., GaleA, P. (2002): Limestone Islands in a Crystal Sea. -Publishers Enterprise Group, Malta, 109 pp.

PiATANeSE, A., TINTI, S. (1998): A revision of the 1693 eastern Sicily earthquake and tsunami. Journ. Geophysical Research 103 B2, 2749-2758.

Pignatelli, C., SANSÒ, P., MAStronUzZI, G. (2009): Evaluation of tsunami flooding using geomorphologic evidence. -Marine Geology 260, 6-18.

Platania, G. (1909): I fenomini marittimi che accompagnarono il terremoto di Messina del 28 Dec 1908. -Rivista Geografica Italiana 16, 154-161. 
Polonia, A., Bonatti, E., CAMERLENGHi, A., LuCChi, R.G, PANieri, G., GASPERINI, L. (2013): Mediterranean megaturbidite triggered by the AD 365 Cretan earthquake and tsunami. Sci. Rept 3, 1285: DOI:10.1038/srep01285.

SCHEFFERS, A., SCHEFFERS, S. 2007. Tsunami deposits on the coastline of west Crete (Greece). Earth and Planetary Science Letters 259, 613-624.

SCHEFfers, A. (2008): Tsunami Boulder Deposits. -In: Shiki, T. et al. (ed.): Tsunamites: 299-313; Elsevier Academic Press.

SCHEFFERS, A., KELLETAT, D., SCHEFFERS, S. (2010): Wave-emplaced coarse debris and megaclasts in Ireland and Scotland: boulder transport in a high-energy littoral environment: a reply. -J. Geology 118, 705-709.

SCICCHITANO, G., MONACO, C., TORTORICI, L. (2007): Large boulder deposits by tsunami waves along the Ionian coast of south-eastern Sicily (Italy). -Marine Geology 238, 75-91.

Scicchitano, G. Costa, B. Di Stefano, A. Longhitano, S.G. Monaco, C. (2010): Tsunami and storm deposits preserved within a ria-type rocky coastal setting (Siracusa, SE Sicily). -Zeitschrift für Geomorphologie Supplementband 54.3, 51-77.

Smedile, A., De Martini, P.M., Pantosti, D., Bellucci, L., Del Carlo, P., Gasperini, L., Pirrotta, C., PoloniA, A., E. Boschi, E. (2011): Possible tsunami signatures from an integrated study in the Augusta Bay offshore (Eastern Sicily - Italy). -Marine Geology 281, 1-13.

Soloviev, S.L., SolovieVA, O.N., Go, C.N., KIM, K.S., SHCHETNIKOV, N.A. (2000): Tsunamis in the Mediterranean Sea 2000 BC-2000 AD. - Kluwer Academic Publishers, Dordrecht. 237 pp.

SYNOLAKIS, C.E. (1987): Runup of solitary waves.- Journ. Fluid Mechanics 185, 523-545.

SYNOLAKIS, C.E. (1991): Tsunami runup on steep slopes: How good linear theory really is.- Natural Hazards 4, 221-234.

TADEPALli, S., SYNOLAKIS, C.E. (1994): The run-up of $N$-waves on sloping beaches.- Proc. Royal Society London A, 445, 99-112.

TINTI, S., MARAMAI, A., GRAZIANI, L. ( 2004): The new catalogue of Italian tsunamis. Natural Hazards 33, 439-465.

Tinti, S., Armigliato, A., PAgnoni, G., Zaniboni, F. (2005): Scenarios of giant tsunamis of tectonic origin in the Mediterranean. -Paper No. 464, ISET Journal of Earthquake Technology 42.4,171-188.

TORAB, M., DALAL, N., NOUR, N. (2011): Geomorphology of mega boulders in Alam Al-Rum north western coast Egypt.-The Egyptian Journal of Environmental Change 3, 7-21.

UK HydRograPhIC OFFICE (2003): Chart 211 Plans in the Maltese Islands- Hydrographic Office, Taunton.

VAN NUFFELEN, P.E.R. (2006): Earthquakes in A.D. 363-368 and the date of Libanius, Oratio 18. The Classical Quarterly (New Series) 56.2, 657-661. 
VÖtT, A., BRÜCKNER, H., MAYA, M., LANG, F., HERD, R., BROCKMÜLLER, S. (2008): Strong tsunami impact on the Bay of Aghios Nikolaos and its environs (NW Greece) during Classical-Hellenistic times. -Quaternary International 181, 105-122. 


\section{TABLES}

Table 1 Summary of studies of extreme wave evidence on coasts opposed to Malta.

\begin{tabular}{|c|c|c|c|}
\hline Location & Azimuth & $\begin{array}{c}\text { Fetch } \\
(\mathbf{k m})\end{array}$ & Authors \\
\hline $\begin{array}{l}\text { Ionian Sea/ } \\
\text { East Sicily }\end{array}$ & NNE & 150 & $\begin{array}{l}\text { PARESCHI ET AL (2006), SCICCHITANO ET AL (2010, } \\
\text { 2007), BARBANO ET AL (2009 a, b, 2010, 2011), } \\
\text { DE MARTINI ET AL (2010), SMEDILE ET AL (2011), }\end{array}$ \\
\hline $\begin{array}{l}\text { Apulia/ } \\
\text { Calabria }\end{array}$ & NNE & 550 & PigNATELLI ET AL (2009). \\
\hline Tunisia & $\begin{array}{l}\text { NW- } \\
\text { SW }\end{array}$ & 250 & FRÉBOURG ET AL (2010), MAY ET AL (2010). \\
\hline Algeria & NW & $\begin{array}{l}700- \\
1300\end{array}$ & MAOUCHE ET AL (2009). \\
\hline Greece/Crete & NE-E & $\begin{array}{l}600- \\
1000\end{array}$ & $\begin{array}{l}\text { SCHEFFERS \& SCHEFFERS (2007), BRUINS ET AL (2008), } \\
\text { SCHEFFERS (2008), VÖTT ET AL (2008). }\end{array}$ \\
\hline Libya/Egypt & SW-SE & 320 & TORAB ET AL (2011), VAN NUFFELEN (2006). \\
\hline
\end{tabular}

Table 2: Topographic characteristics of study sites.

\begin{tabular}{|l|l|l|l|c|}
\hline \multicolumn{1}{|c|}{ Site } & Planform & \multicolumn{1}{c|}{ Profile } & \multicolumn{1}{c|}{ Relief } & Encroached \\
\hline Qorrot & Linear & Ramp over sea cliff & Up to $>12 \mathrm{~m}$ & $\mathrm{~N}$ \\
\hline Quarry & Linear & Ramp over sea cliff & Up to $>15 \mathrm{~m}$ & $?$ \\
\hline Comino col & Headland & Cliffed ridge with col & Up to $>20 \mathrm{~m}$ & $\mathrm{~N}$ \\
\hline NW Comino & Linear & Platform & Up to $6 \mathrm{~m}$ & $\mathrm{~N}$ \\
\hline Ahrax Point & Headland & Cliffed ridge with col & Up to $>20 \mathrm{~m}$ & $\mathrm{~N}$ \\
\hline Armier Point & Headland & Platform & $<1 \mathrm{~m}$ & $\mathrm{Y}$ \\
\hline Water Park & Headland & Platform & $<1 \mathrm{~m}$ & $\mathrm{~N}$ \\
\hline White Tower & Headland & Slope over platform & Up to $14 \mathrm{~m}$ & $\mathrm{~N}$ \\
\hline Xghajra & Linear & Platforms over sea cliff & Up to $>8 \mathrm{~m}$ & $\mathrm{Y}$ \\
\hline Żonqor & Linear & Rock platforms & Up to $6 \mathrm{~m}$ & $\mathrm{Y}$ \\
\hline
\end{tabular}


Table 3. Minimum tsunami and storm wave sizes required to detach boulders of $b$-axis $>1 \mathrm{~m}$ at White Tower and Water Park sites using the model of Nandasena et al (2011).

\begin{tabular}{|l|c|c|c|c|}
\hline & $\mathbf{n}>\mathbf{1 m} \boldsymbol{b}$ & $\begin{array}{c}\mathbf{M i n}_{\mathbf{t}} \\
(\mathbf{m})\end{array}$ & $\begin{array}{c}\mathbf{M i n}_{\mathbf{s}} \\
(\mathbf{m})\end{array}$ & $\mathbf{\%}_{\mathbf{s}}>\mathbf{9 m}$ \\
\hline $\begin{array}{l}\text { White } \\
\text { Tower }\end{array}$ & & & & 15.7 \\
\hline Type 1 & 76 & 1.02 & 4.09 & \\
\hline Type 2 & 36 & 4.26 & 17.06 & \\
\hline Type 3 & 15 & 3.69 & 14.77 & \\
\hline $\mathbf{\Sigma}$ & $\mathbf{1 2 7}$ & & & \\
\hline $\begin{array}{l}\text { Water } \\
\text { Park }\end{array}$ & & & & 29.0 \\
\hline Type 1 & 12 & 1.08 & 4.32 & \\
\hline Type 2 & 15 & 2.78 & 11.14 & \\
\hline Type 3 & 4 & 3.62 & 14.47 & \\
\hline $\mathbf{\Sigma}$ & $\mathbf{3 1}$ & & & \\
\hline
\end{tabular}

Key:-

\begin{tabular}{|l|l|}
\hline $\mathbf{n}>\mathbf{1 m} \boldsymbol{b}$ & Number of boulders of intermediate axis $>1$ metre \\
\hline $\operatorname{Min} \mathbf{H}_{\mathbf{t}}$ & Minimum height of tsunami wave to move largest boulder in category \\
\hline $\mathbf{M i n} \mathbf{H s}$ & Minimum height of storm wave to move largest boulder in category \\
\hline $\mathbf{H}_{\mathbf{s}}>\mathbf{9 m}$ & $\begin{array}{l}\text { Percentage of boulders per site exceeding the competence of } 9 \mathrm{~m} \text { storm } \\
\text { waves. }\end{array}$ \\
\hline
\end{tabular}

Table 4: Retrodicted values of tsunami minimum wave height and shoreline velocity at the study sites for solitary and single $\mathbf{N}$-waves. Subscript values show the submarine contour used to define slope. The sea level rise of the most recent 2000 years (FURLANI ET AL 2013) implies that the retrodicted values should be regarded as underestimates.

\begin{tabular}{|c|c|c|c|c|c|c|}
\hline Site & $H_{\text {maxobs }}(\mathrm{m})$ & Gdt (cot) & $\mathbf{H}_{\mathrm{t}}(\mathrm{m})$ & $\mathrm{NH}_{\mathrm{t}}(\mathrm{m})$ & $\mathrm{V}_{\mathrm{r}}\left(\mathrm{ms}^{-1}\right)$ & $\mathrm{Nv}_{\mathrm{r}}\left(\mathrm{ms}^{-1}\right)$ \\
\hline $\mathrm{A} \hbar \operatorname{rax} \mathrm{Pt}_{10}$ & 22.00 & 2.50 & 3.83 & 2.99 & 12.26 & 10.83 \\
\hline Aћrax col 10 & 22.00 & 7.51 & 2.47 & 1.93 & 9.84 & 8.69 \\
\hline Ahrax $_{20}$ & 22.00 & 5.85 & 2.73 & 2.13 & 10.34 & 9.14 \\
\hline $\mathrm{CCol}_{30}$ & 16.50 & 11.23 & 1.56 & 1.21 & 7.82 & 6.90 \\
\hline $\mathrm{GG}_{20}$ & 8.50 & 18.87 & 0.74 & 0.58 & 5.40 & 4.77 \\
\hline $\mathrm{WTR}_{20}$ & 10.50 & 14.90 & 0.97 & 0.76 & 6.16 & 5.44 \\
\hline Qor $_{20}$ & 11.40 & 10.00 & 1.21 & 0.95 & 6.90 & 6.09 \\
\hline Qry $_{20}$ & 13.40 & 7.52 & 1.55 & 1.21 & 7.79 & 6.88 \\
\hline Zonq $_{20}$ & 8.16 & 11.24 & 0.89 & 0.69 & 5.90 & 5.21 \\
\hline
\end{tabular}

Key:-
\begin{tabular}{|l|l|}
\hline $\mathbf{H}_{\text {maxobs }}$ & Maximum observed elevation of tsunami sediments \\
\hline $\mathbf{H}_{\mathbf{t}}$ & Estimated minimum tsunami height at shoreline, solitary wave \\
\hline $\mathbf{G d t}$ & Offshore gradient to depth indicated by the subscript value in column 1 \\
\hline $\mathbf{N H}_{\mathbf{t}}$ & Estimated minimum tsunami height at shoreline, single N-wave \\
\hline $\mathbf{v}_{\mathbf{r}}$ & Estimated mean velocity at shoreline, solitary wave \\
\hline $\mathbf{N v}_{\mathbf{r}}$ & Estimated mean velocity at shoreline, single N-wave \\
\hline
\end{tabular}




\section{FIGURES}

Fig.1 Study site location map of the Maltese Islands (study sites underlined).

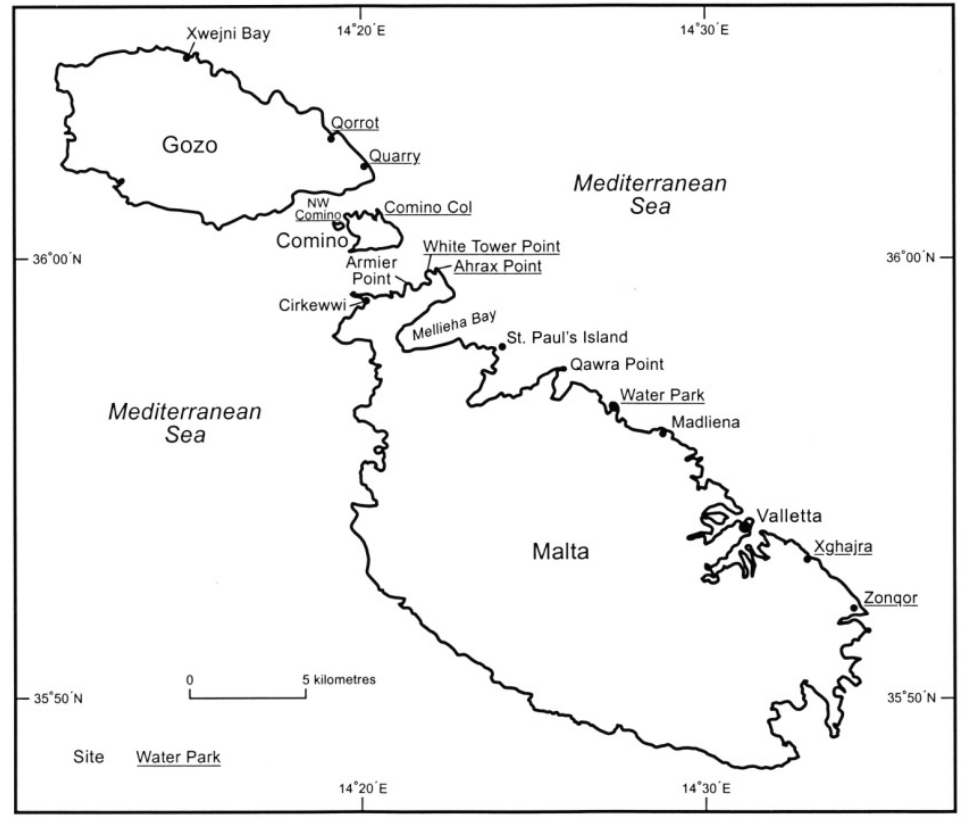

Fig. 2. Quarry site: field image and surveyed profile. A boulder berm overlooks the clean washed bedrock slope below, and a detachment scarp representing a boulder source. Above the berm a boulder spread with diminishing clast size, extends upslope, the fining inland sequence indicating transport from below.

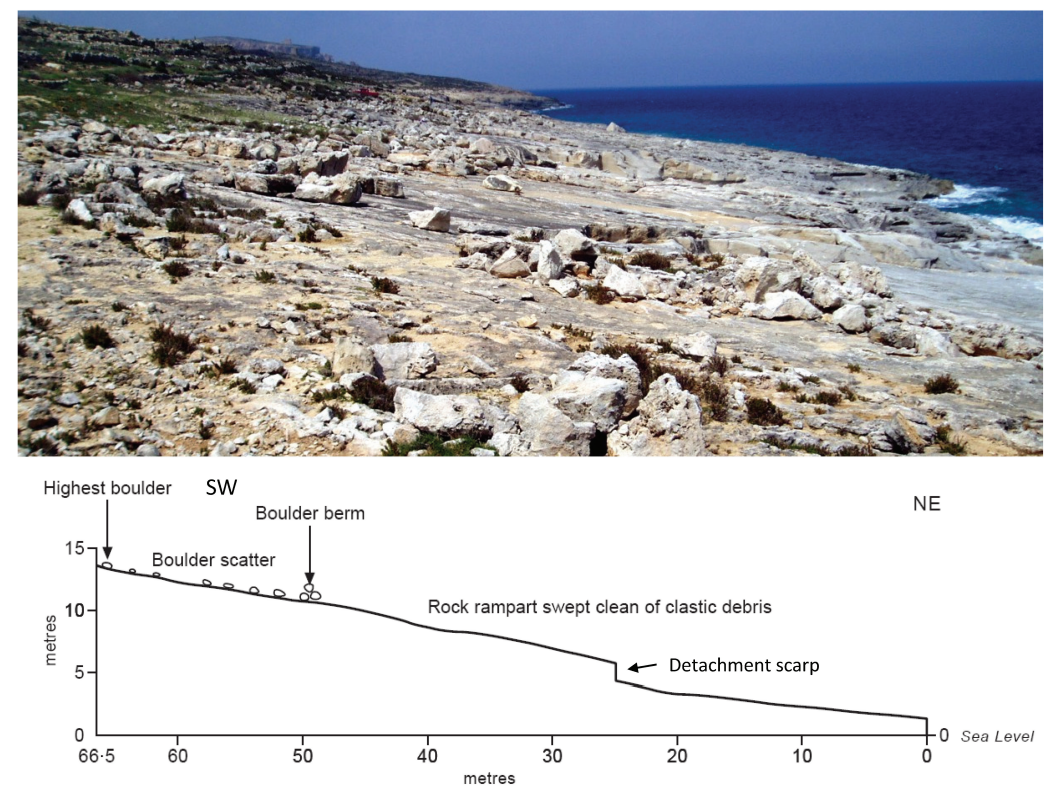


Fig. 3. Map of Ahrax study site showing boulder lines and spreads, erosional features and inferred lines of water flow.

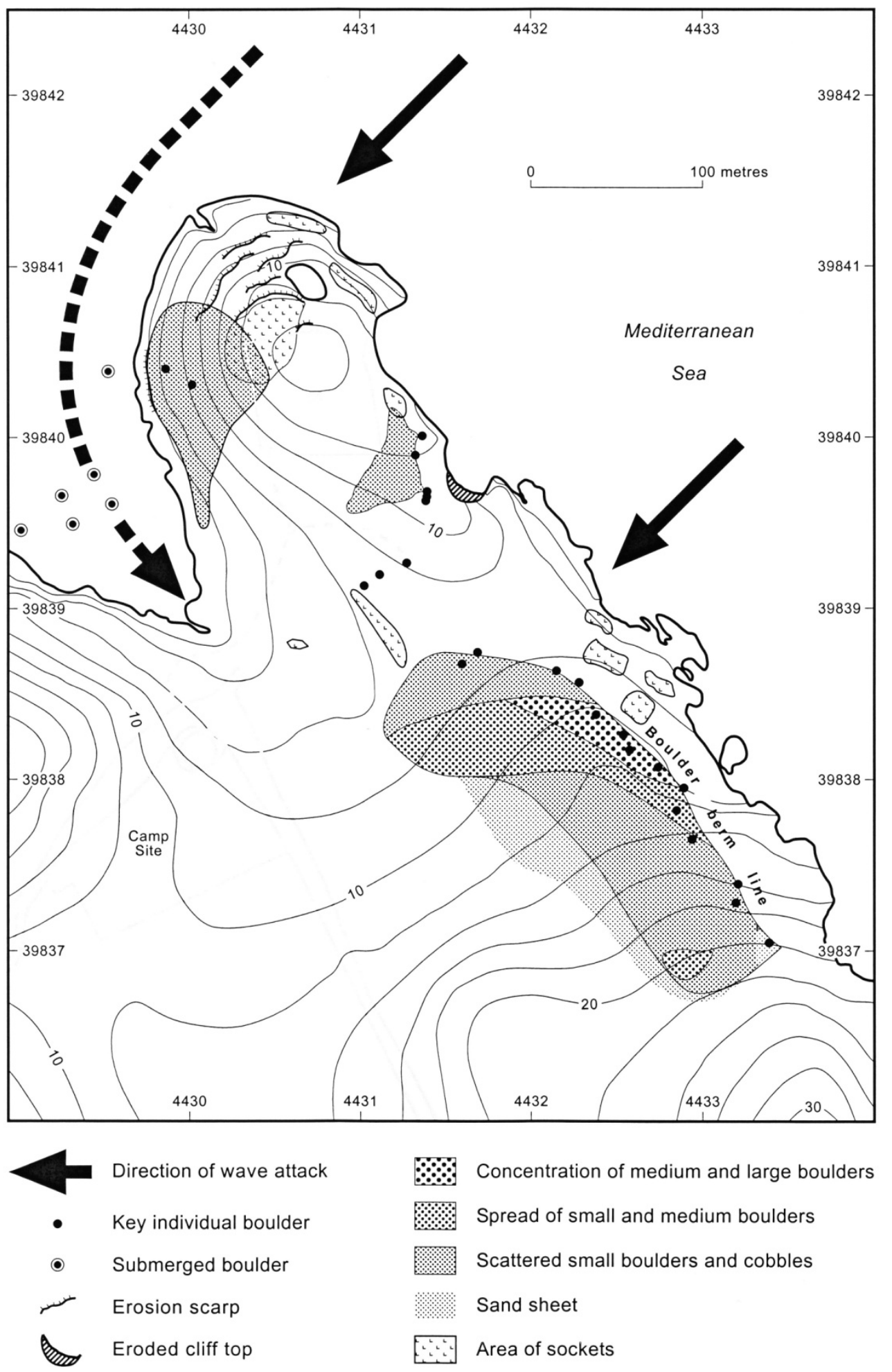


Fig. 4. View of Ahrax ridge showing boulder line extending from the foreground, facing the clean shoreward slope, with vegetation indicating landward spread of finer sediment. A broad shallow valley runs across the middle ground leading to the col at left. The triple split boulder is visible (centre) landward of the bight in the sea cliff; the boulder is $\sim 1.4 \mathrm{~m}$ in height.

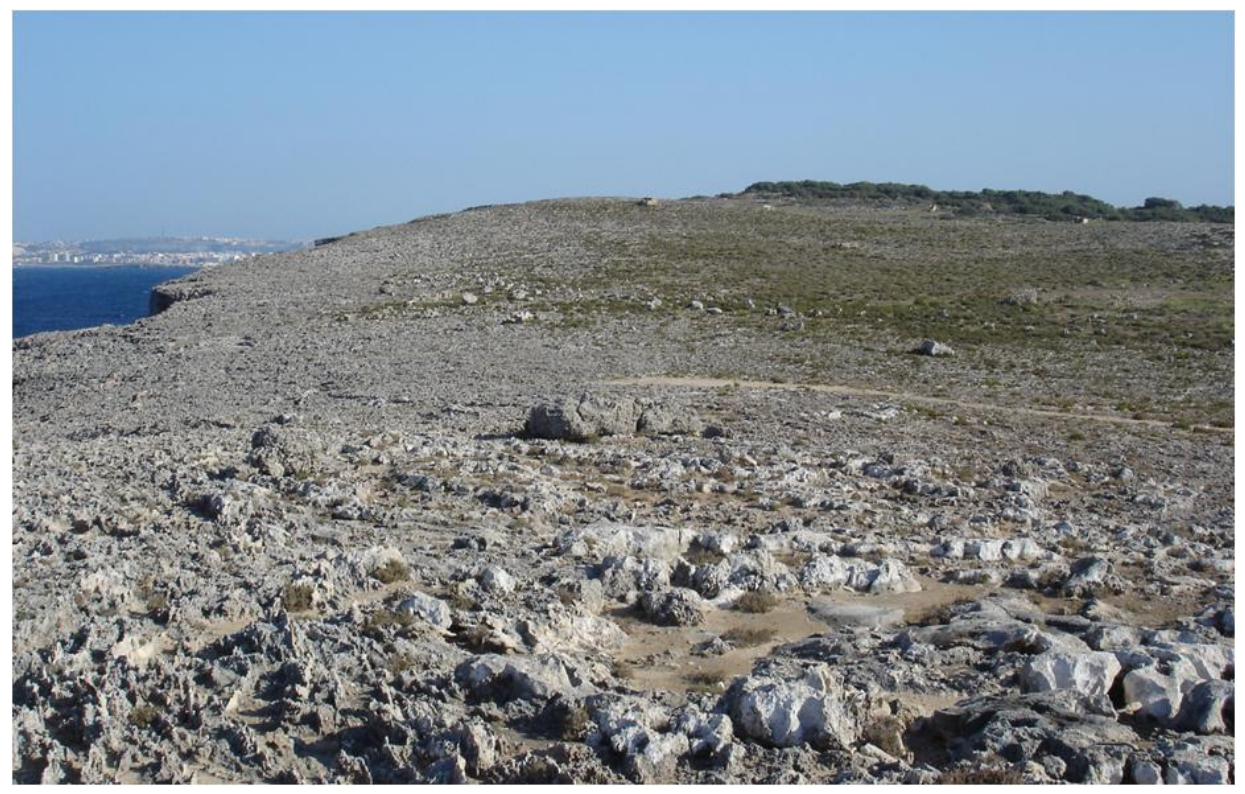

Fig. 5. A large conglomerate boulder detached from, lifted and dumped back on to its own scarp at $7.5 \mathrm{~m}$ asl. The high energy of this limited movement has split the boulder into three fragments. The fact that the boulder has remained in place implies that no event of similar magnitude has occurred subsequently, for it would have been readily able to move the individual broken fragments. Qorrot site.

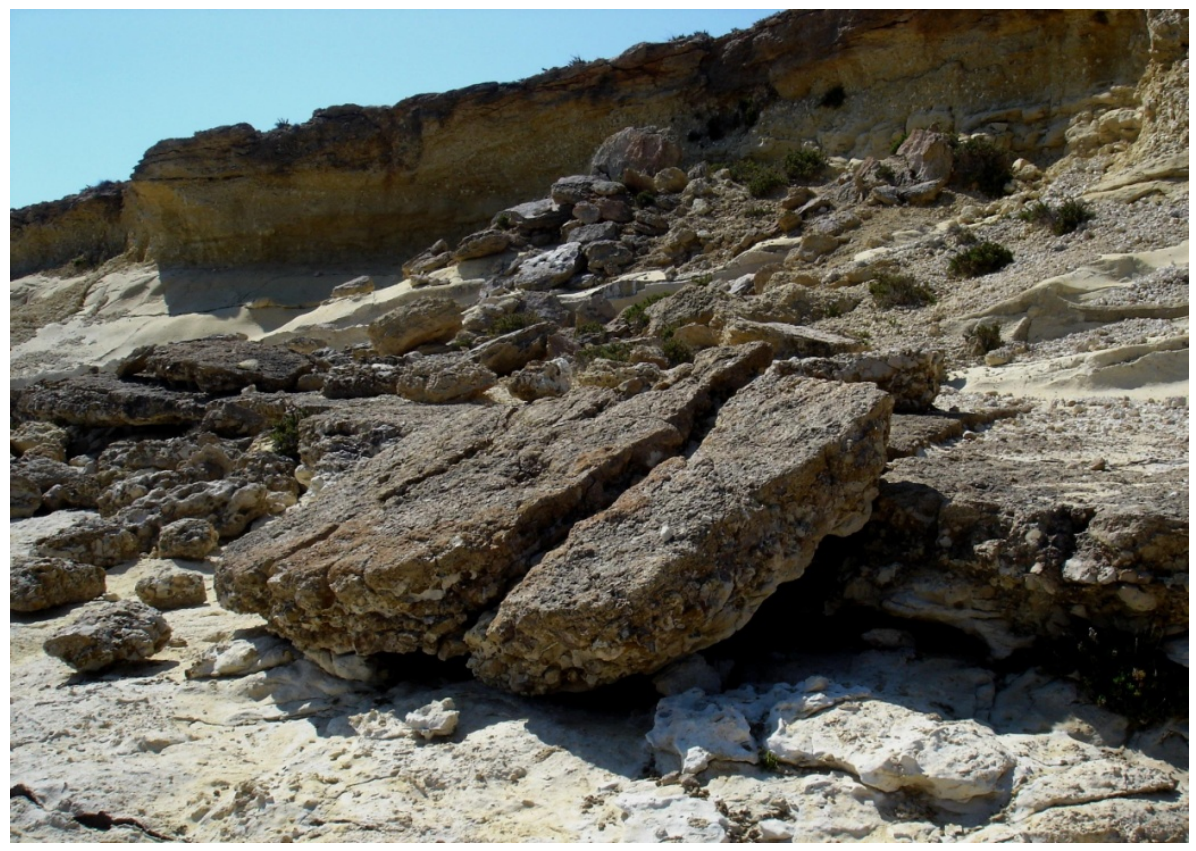


Fig. 6. Qorrot site: field image and surveyed profile. The Phosphorite Conglomerate scarp at $7.5 \mathrm{~m}$ asl, centre, is the source of the abundant eroded clasts distributed upslope of the scarp itself, indicating wave runup to $>12 \mathrm{~m}$ asl. Below the scarp is the clean washed surface of Globigerina Limestone with minimal clasts. Foreground are two imbricated boulders. Note: PNB $=$ Phosphoritic Comglomerate.
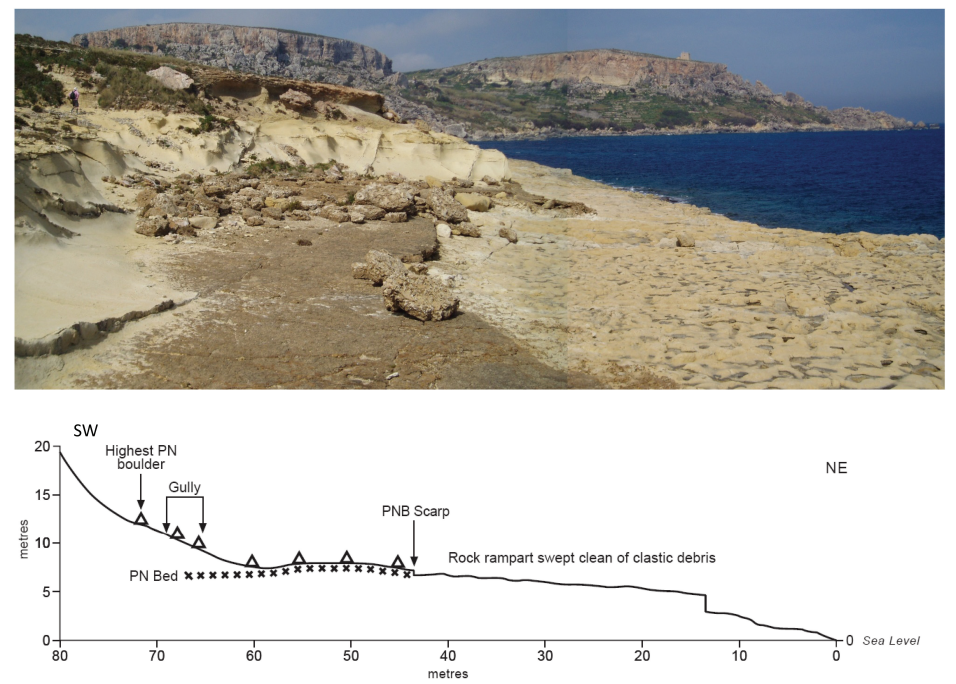

Fig. 7. Scoured terrain: chaotically rough and incoherently dissected bedrock terrain with irregular hummocks and basins of $\sim 1 \mathrm{~m}$ relative relief.

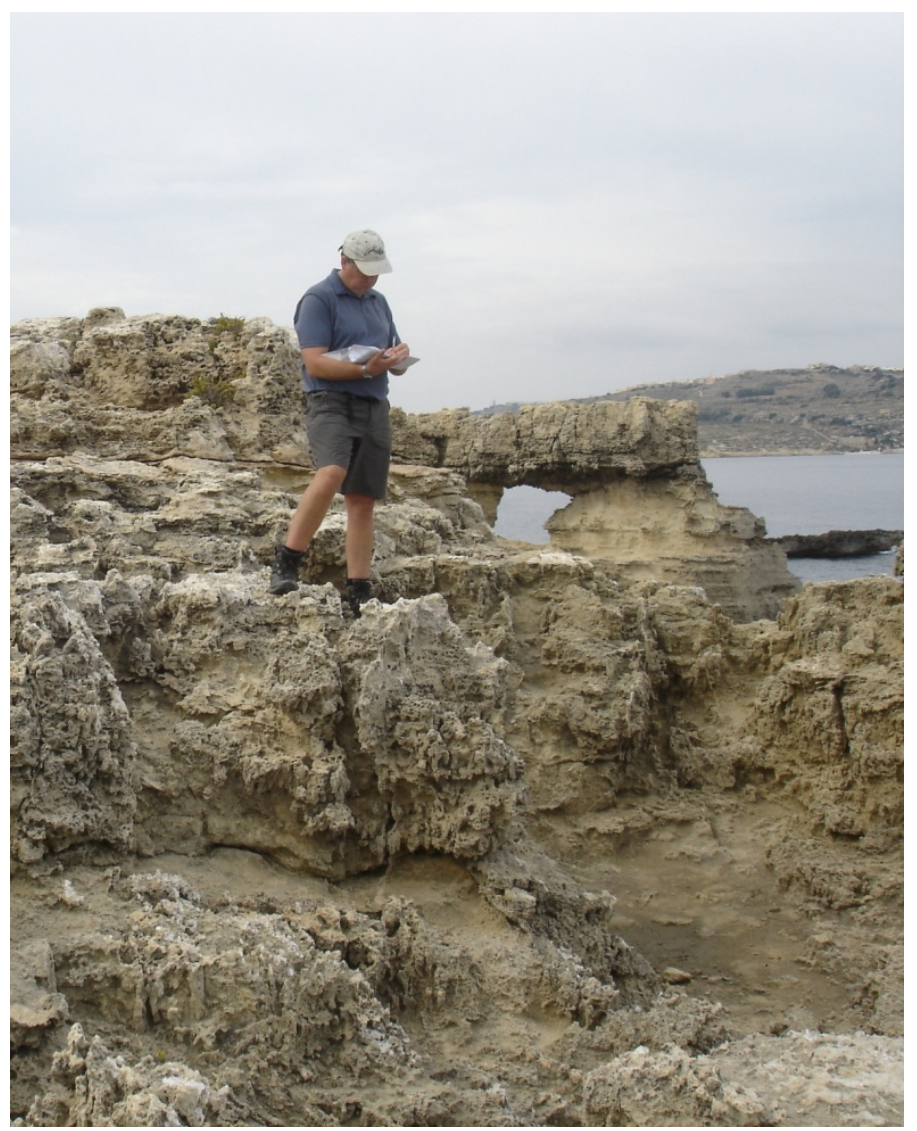


Fig. 8. A socket some $5 \mathrm{~m} \mathrm{x} 3 \mathrm{~m}$ in plan dimensions and $0.5 \mathrm{~m}$ deep indenting a rock surface at an altitude of $\sim 10 \mathrm{~m}$ asl at Ahrax Point.

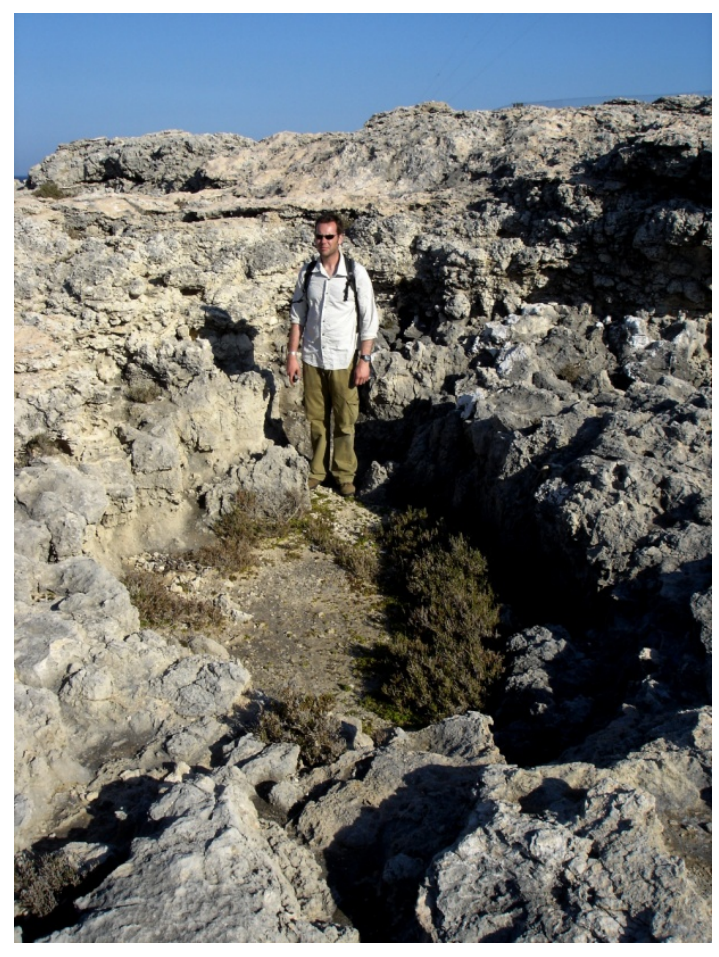

Fig. 9. Comparative height distribution of some extreme wave indicators at the principal study sites. Note that $\mathrm{H}_{\mathrm{t}}$ at some sites is a potential underestimate, as coastal development may obscure the highest extent of sedimentary signatures, including boulders. Where bioform-encrusted boulders are present, the lowest erosion elevation is formally and conservatively assumed as $-0.5 \mathrm{~m}$ asl.

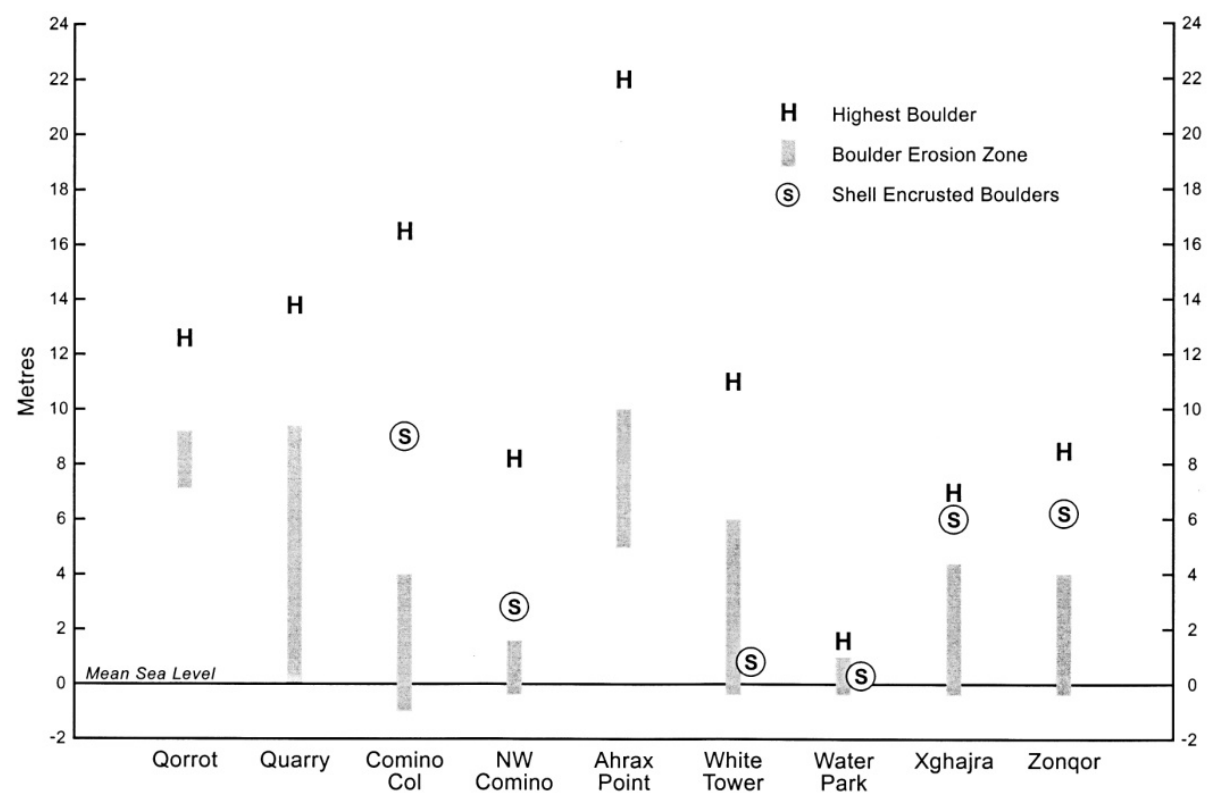


Fig. 10. Calculated storm breaking wave heights required to detach boulders now deposited at White Tower (A) and Water Park (B) sites, using the model of NANDASENA ET AL (2011). A significant proportion ( $18.4 \% 24.7 \%$ overall) exceeds the likely maximum storm wave height in Malta; it is inferred that a tsunami wave would be required in order to detach these large boulders.
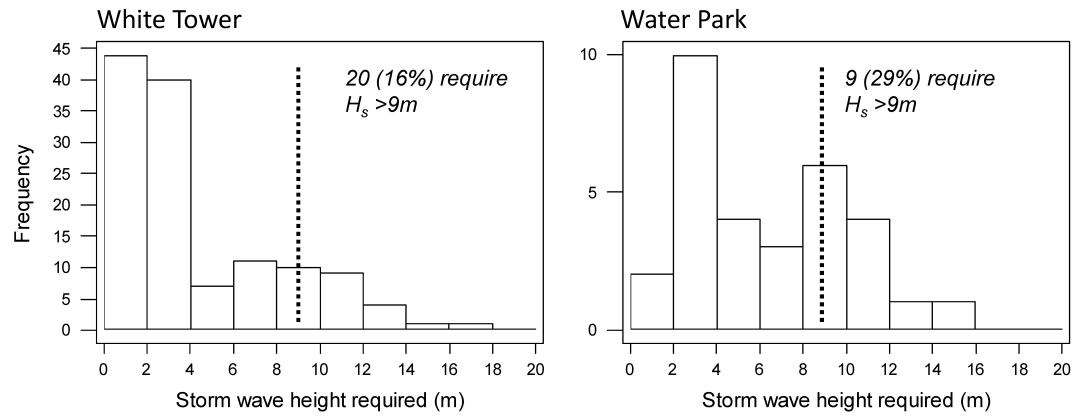